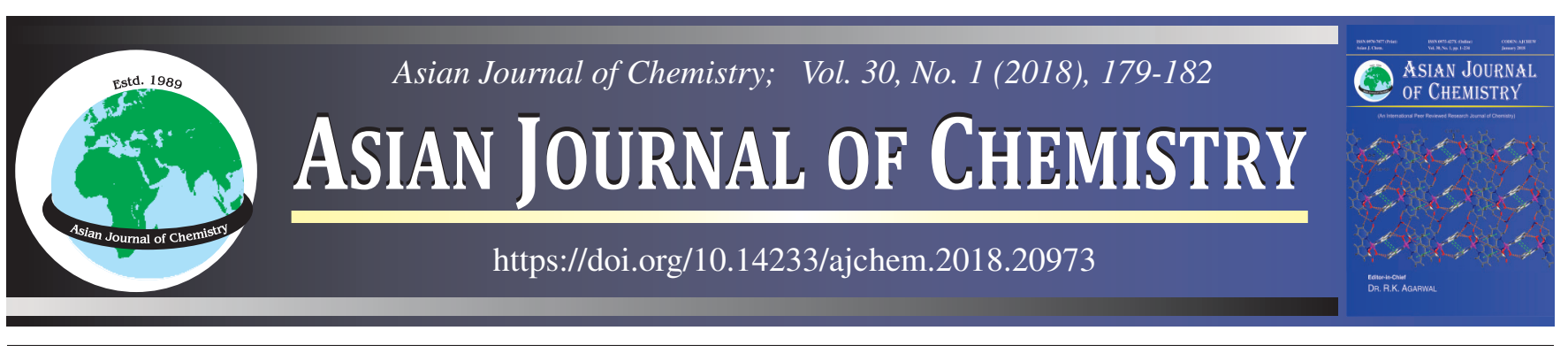

\title{
Kinetics and Mechanism of Oxidation of Diclofenac Sodium by Keggin Type 12-Tungstocobalt(III) in Aqueous Medium
}

\author{
M. SAnJAnA ${ }^{1, *}$, A.K. Patnaik ${ }^{2}$, P. Mohanty ${ }^{2}$ and S.K. Badamali ${ }^{3}$
}

${ }^{1}$ Department of Chemistry, Christ College, Cuttack-753 008, India

${ }^{2}$ Post Graduate Department of Chemistry, Ravenshaw University, Cuttack-753 001, India

${ }^{3}$ Post Graduate Department of Chemistry, Utkal University, Bhubaneswar-751 004, India

*Corresponding author: E-mail: msanjanaa@gmail.com

Received: 14 August 2017;

Accepted: 29 September 2017;

Published online: 30 November 2017;

AJC-18672

\begin{abstract}
The kinetics of electron transfer reaction of diclofenac sodium with 12-tungstocobaltate (III) complex has been studied spectrophotometrically over the range $2.0 \times 10^{-3} \leq$ [diclofenac sodium] $\leq 6.0 \times 10^{-3} \mathrm{~mol} / \mathrm{L}, 6.03 \leq \mathrm{pH} \leq 8.0$ and at $293 \leq \mathrm{T} \leq 308 \mathrm{~K}$ in aqueous medium at constant ionic strength I ( $0.5 \mathrm{~mol} / \mathrm{L}$ sodium perchlorate). The electron transfer reaction showed pseudo-first order dependence in [diclofenac sodium] and [12-tungstocobaltate(III)] and less than unit order in $\left[\mathrm{OH}^{-}\right]_{\mathrm{T}}$. The activation parameters calculated for the electron transfer reaction favoured the formation of a precursor complex between the reactants. The product is characterized by FTIR and NMR spectra and is found to be [2-(2,6-dichloro phenylamino)phenyl]methanol.

Keywords: Kinetic, Oxidation, Diclofenac sodium, 12-Tungstocobaltate(III), Keggin Type.
\end{abstract}

\section{INTRODUCTION}

Non-steroidal anti-inflammatory drugs (NSAIDs) are of great significance [1] due to their large pharmaceutical importance. Diclofenac [2-(2,6-dichloranilino)phenylacetic acid] is the most potent member of this class of drugs. It works by reducing the production of prostaglandins [2], the chemical that causes pain, fever and inflammation. Diclofenac blocks the enzyme (cyclooxygenase) that produces prostaglandin, resulting in decrease in production of prostaglandin and hence subsequent relief from pain. The drug is used in the form of its sodium salt due to its low solubility in water. This analgesic drug is used for the treatment of osteoarthritis, rheumatoid arthritis and ankylo spondylitis [3,4]. This drug has also many side effects such as nausea, heartburn, diarrhoea, constipation, gastritis, headache, drowsiness and dizziness. Its presence in wastewater is harmful for ecological environment. The oxidative degradation of the drug has large significance [5] because it may through light how to reduce the diclofenac content in waste water.

The oxidant is 12-tungstocobalt(III) $\left(\mathrm{Co}^{\mathrm{III}} \mathrm{W}_{12} \mathrm{O}_{40}{ }^{5-}\right.$ or $\left.\mathrm{Co}^{\mathrm{III}} \mathrm{W}^{5-}\right)$ is a Keggin type cluster and its redox potential is $1.0 \mathrm{~V}$ [6]. It is a well known outer sphere oxidant $[7,8]$ and a mild oxidant. Its electron transfer reaction with ascorbic acid [9] glutathione [1]0, citric acid [11], DL-methionine [12], L-cysteine [13], NADH [14] and L-cystine [15] have been studied. In order to examine the oxidative degradation of diclofenac sodium, its oxidation reaction with the above oxidant has been studied.

\section{EXPERIMENTAL}

$\mathrm{Co}^{\mathrm{III}} \mathrm{W}_{12} \mathrm{O}_{40}{ }^{5-}$ was prepared as reported by McAuley et al. [9]. It was characterized spectrophotometrically [16] at 388 $\mathrm{nm}\left(\varepsilon_{388}=1150 \pm 2 \mathrm{~L}^{-1} \mathrm{~mol}^{-1} \mathrm{~cm}^{-1}\right)$. A.R. grade chemicals were used and conductivity water was used for preparing different solutions. The redox reaction was studied at $\mathrm{pH}=6.03$ to 8.0 using Systronics (India) digital $\mathrm{pH}$ meter which was standardized by suitable buffers. The phosphate buffer has been used to maintain $\mathrm{pH}$ of different solutions.

The CECIL CE 7200 UV-visible spectrophotometer equipped with CE 2024 thermoelectric controller was used for measuring absorbance for the kinetic studies.

Kinetic measurements: In order to follow the kinetics, pseudo first order conditions were maintained. The maximum mole ratio of reductant/oxidant was 12:1. The reaction was initiated by mixing previously thermostated solutions of diclofenac sodium and $\mathrm{CoW}_{12} \mathrm{O}_{40}{ }^{5-}$ and conductivity water. The redox reaction was followed at $388 \mathrm{~nm}$. The absorbance due to oxidant decreased with time. The pseudo-first order rate constant $\left(\mathrm{k}_{\mathrm{obs}}\right)$ were determined from the slope of the linear plot of $\ln \left(\mathrm{A}_{\mathrm{t}}-\mathrm{A}_{\infty}\right)$ versus $\mathrm{t}$ (s) using Excel program.

$$
\ln \left(\mathrm{A}_{\mathrm{t}}-\mathrm{A}_{\infty}\right)=\ln \left(\mathrm{A}_{0}-\mathrm{A}_{\infty}\right)-\mathrm{k}_{\mathrm{obs} . \mathrm{t}}
$$


where $A_{t}$ and $A_{\infty}$ are the absorbance of the reaction mixture at time ' $t$ ' and at equilibrium respectively. The reaction was studied up to $80 \%$ completion and rate constants were reproducible within $\pm 5 \%$. The correlation coefficients of the plots which were used to determine $\mathrm{k}_{\mathrm{obs}}$ were found to be 0.99 in most of the cases.

\section{RESULTS AND DISCUSSION}

UV-visible spectral scan of the reaction mixture was studied spectrophotometrically at different time intervals (Fig. 1). The decrease in absorbance at $\lambda_{\max } 388 \mathrm{~nm}$ with time was observed on mixing the diclofenac sodium with 12-tungstocobaltate(III) and simultaneously increase of a new peak at $624 \mathrm{~nm}$ appeared due to the formation of $\mathrm{Co}^{\mathrm{II}} \mathrm{W}_{12} \mathrm{O}_{40}$. The redox reaction was monitored at $\lambda_{\max } 388 \mathrm{~nm}$ under pseudo-first order conditions keeping $\left[\mathrm{Co}^{\mathrm{III}} \mathrm{W}_{12} \mathrm{O}_{40}{ }^{5-}\right]=5.0 \times 10^{-4} \mathrm{~mol} / \mathrm{L}$ and varying [diclofenac sodium] from $2.0 \times 10^{-3}$ to $6.0 \times 10^{-3} \mathrm{~mol} / \mathrm{L}$ and $\mathrm{pH}$ from 6.03 to 8.0. The pseudo-first order rate constants were found to increase with the increase in the concentration of reductant showing first order dependence of rate with [diclofenac sodium] (Fig. 2).

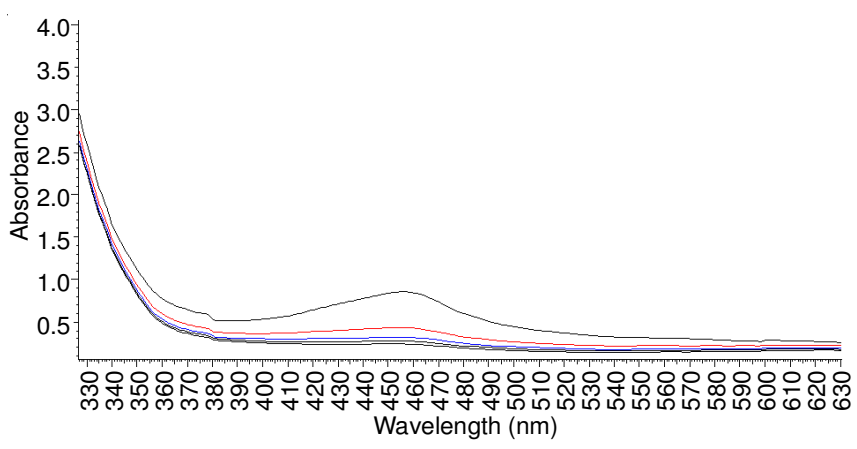

Fig. 1. UV-visible spectral scan of the reaction mixture at different time intervals. $\left[\mathrm{Co}^{\text {III }} \mathrm{W}_{12} \mathrm{O}_{40}{ }^{5-}\right]=5.0 \times 10^{-4} \mathrm{~mol} / \mathrm{L}$, [diclofenac sodium $]=$ $2.0 \times 10^{-3} \mathrm{~mol} / \mathrm{L}, \mathrm{pH} 6.03$ and temperature $298 \mathrm{~K}$

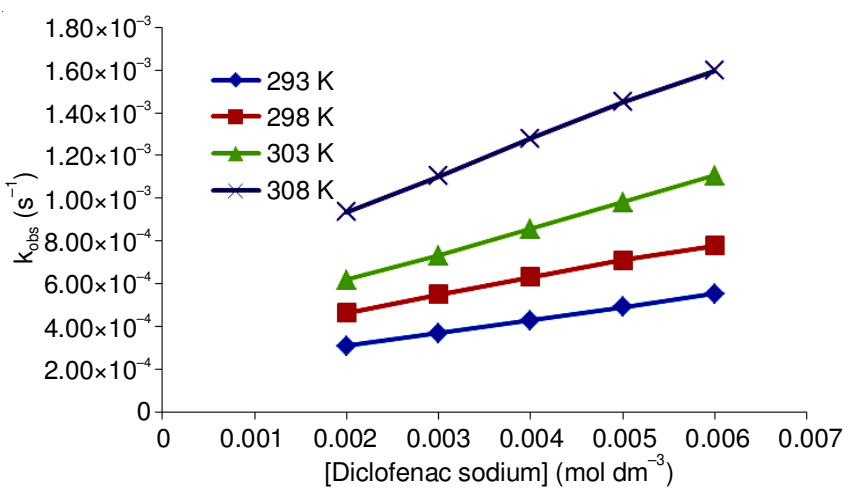

Fig. 2. Plot of $\mathrm{k}_{\mathrm{obs}}$ versus [diclofenac sodium] at different temperatures. Temperature was varied from 293 to $308 \mathrm{~K}$ at fixed $\mathrm{pH}$. [ $\left.\mathrm{Co}^{\mathrm{III}} \mathrm{W}_{12} \mathrm{O}_{40}{ }^{5-}\right]$ $=5.0 \times 10^{-4} \mathrm{~mol} / \mathrm{L}$ ionic strength $\mathrm{I}=0.3 \mathrm{~mol} / \mathrm{L}, \mathrm{pH}=6.03$, [diclofenac sodium] was varied from $2.0 \times 10^{-3}$ to $6.0 \times 10^{-3} \mathrm{~mol} / \mathrm{L}$

The pseudo first order rate constants were measured by varying the $\mathrm{pH}$ from 6.08 to 8.0 at four different temperatures, 293 to $308 \mathrm{~K}$ keeping all other parameters constants. The plots of $\mathrm{k}_{\mathrm{obs}}$ versus $\mathrm{pH}$ at four different temperatures (Fig. 3) shows that the electron transfer reaction could not be studied at higher $\mathrm{pH}$ because the oxidants, $\mathrm{Co}(\mathrm{III})$ clusters will undergo base hydrolysis.

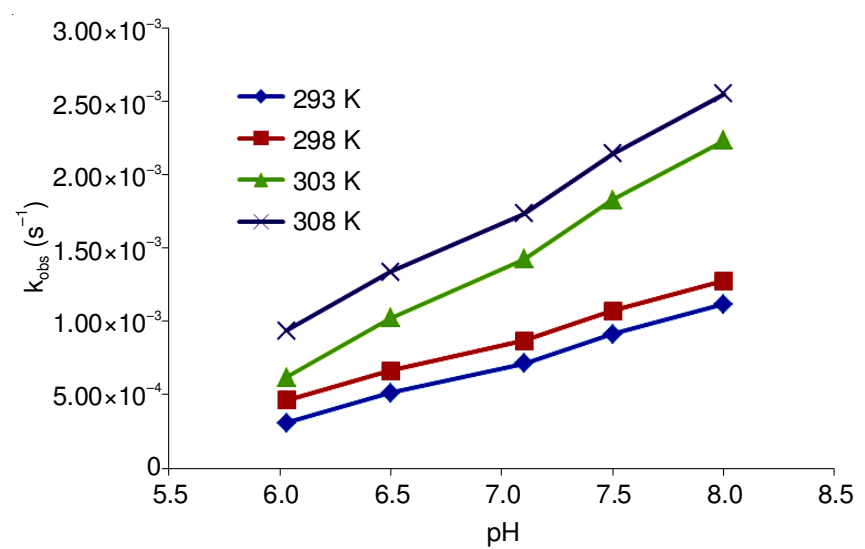

Fig. 3. Plot of $\mathrm{k}_{\mathrm{obs}}$ versus $\mathrm{pH}$ at fixed $\left[\mathrm{Co}^{\mathrm{III}} \mathrm{W}_{12} \mathrm{O}_{40}{ }^{5-}\right]\left(5.0 \times 10^{-4} \mathrm{~mol} / \mathrm{L}\right)$, [diclofenac sodium] $3.0 \times 10^{-3} \mathrm{~mol} / \mathrm{L}, \mathrm{pH}$ varied from 6.03 to 8.0 and temperature was varied from 293 to $308 \mathrm{~K}$

Effect of diclofenac sodium: At a fixed $\left[\mathrm{Co}^{\mathrm{III}} \mathrm{W}_{12} \mathrm{O}_{40}{ }^{5-}\right]$ $\left(5 \times 10^{-4} \mathrm{~mol} / \mathrm{L}\right)$, ionic strength $\mathrm{I}=0.3 \mathrm{~mol} / \mathrm{L}, \mathrm{pH}=6.03$, when [diclofenac sodium] was changed from $2.0 \times 10^{-3}$ to $6.0 \times 10^{-3}$ $\mathrm{mol} / \mathrm{L}, 10^{4} \mathrm{k}_{\text {obs }}$ changed from 4.63 to $7.79 \mathrm{~s}^{-1}$ at $298 \mathrm{~K}$. The pseudo first order rate constants were found to increase with the increase in the concentration of diclofenac sodium, showing first order dependence of rate with [diclofenac sodium]. The plot of $\mathrm{k}_{\mathrm{obs}}$ versus [dicofenac sodium] at different temperature and at fixed $\mathrm{pH}$ is shown in Fig. 2.

Effect of variation of $\mathbf{p H}$ on rate: The electron transfer reaction has been carried out in $\mathrm{pH}$ range 6.03 to 8.0. At 298 $\mathrm{K}$, when $\left[\mathrm{Co}^{\mathrm{III}} \mathrm{W}_{12} \mathrm{O}_{40}{ }^{5-}\right]=5.0 \times 10^{-4} \mathrm{~mol} / \mathrm{L}$, [diclofenac sodium] $=3.0 \times 10^{-3} \mathrm{~mol} / \mathrm{L}$ with change in $\mathrm{pH}$ from 6.03 to 8.00 , the $10^{4} \mathrm{k}_{\mathrm{obs}}$ varied from 5.50 to $13.38 \mathrm{~s}^{-1}$. The plot of $\mathrm{k}_{\mathrm{obs}}$ versus $\mathrm{pH}$ at different concentration of diclofenac sodium at $298 \mathrm{~K}$ is shown in Fig. 3. This plot shows that the electron transfer reaction is $\mathrm{pH}$ dependent. By increasing $\mathrm{pH}$, the concentration of conjugate base of diclofenac sodium increases which is a better reductant, hence the rate of reaction increases.

Effect of ionic strength: The effect of ionic strength on the redox reaction was studied by increasing the ionic strength from 0.3 to $1.0 \mathrm{~mol} / \mathrm{L}$. This pseudo first order rate constant was found to be unaffected indicating a charged and a neutral species were involved in the rate determining step.

Effect of temperature: The pseudo first order rate constants were determined by varying the temperature from 293 to $308 \mathrm{~K}$. The oxidant concentration was kept constant and reductant concentration was varied from $2.0 \times 10^{-3}$ to $6.0 \times 10^{-3} \mathrm{~mol} / \mathrm{L}$ at constant $\mathrm{pH}$ and varying temperature. The $\mathrm{k}_{\mathrm{obs}}$ was found to increase with increase in temperature. The plot of $\mathrm{k}_{\mathrm{obs}}$ versus [diclofenac sodium] at constant $\mathrm{pH}$ and varying temperature is shown in Fig. 2. Basing on the above experimental facts the mechanism of the reaction is delineated as follows.

\section{Mechanism}

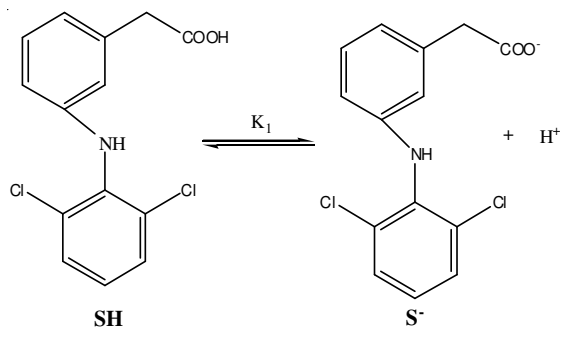




$$
\begin{gathered}
\mathrm{S}^{-}+\left[\mathrm{Co}^{\mathrm{III}} \mathrm{W}_{12} \mathrm{O}_{40}^{5-}\right] \stackrel{\mathrm{k}}{\longrightarrow} \text { Product } \\
\mathrm{K}_{1}=\frac{\left[\mathrm{S}^{-}\right]_{\mathrm{e}}\left[\mathrm{H}^{+}\right]}{[\mathrm{SH}]_{\mathrm{e}}} \\
{\left[\mathrm{S}^{-}\right]_{\mathrm{e}}=\frac{\mathrm{K}_{1}[\mathrm{SH}]_{\mathrm{e}}}{\left[\mathrm{H}^{+}\right]}} \\
\text {Rate }=\mathrm{k}_{1}\left[\mathrm{~S}^{-}\right]\left[\mathrm{Co}^{\mathrm{III}} \mathrm{W}_{12} \mathrm{O}_{40}^{5-}\right]
\end{gathered}
$$

Substituting $[\mathrm{S}]_{\mathrm{e}}$ in eqn. 2 we have

$$
\begin{aligned}
& \text { Rate }=\frac{\mathrm{k}_{1} \mathrm{~K}_{1}[\mathrm{SH}]_{\mathrm{e}}\left[\mathrm{Co}^{\mathrm{II}} \mathrm{W}_{12} \mathrm{O}_{40}^{5-}\right]}{\left[\mathrm{H}^{+}\right]} \\
& {[\mathrm{SH}]_{\mathrm{T}} }=[\mathrm{SH}]_{\mathrm{e}}+\left[\mathrm{S}^{-}\right]_{\mathrm{e}} \\
&=[\mathrm{SH}]_{\mathrm{e}}+\frac{\mathrm{K}_{1}[\mathrm{SH}]_{\mathrm{e}}}{\left[\mathrm{H}^{+}\right]} \\
&=[\mathrm{SH}]_{\mathrm{e}}\left(1+\frac{\mathrm{K}_{1}}{\left[\mathrm{H}^{+}\right]}\right) \\
&=[\mathrm{SH}]_{\mathrm{e}}\left(\frac{\left[\mathrm{H}^{+}\right]+\mathrm{K}_{1}}{\left[\mathrm{H}^{+}\right]}\right) \\
& {[\mathrm{SH}]_{\mathrm{e}} }=[\mathrm{SH}]_{\mathrm{T}}\left(\frac{\left[\mathrm{H}^{+}\right]}{\left[\mathrm{H}^{+}\right]+\mathrm{K}_{1}}\right)
\end{aligned}
$$

Putting the value of $[\mathrm{SH}]_{\mathrm{e}}$ from eqn. 4 in eqn. 3 , we have

$$
\begin{gathered}
\text { Rate }=\frac{\mathrm{k}_{1} \mathrm{~K}_{1}\left[\mathrm{SH}_{\mathrm{T}}\left[\mathrm{Co}^{\mathrm{III}} \mathrm{W}_{12} \mathrm{O}_{40}^{5-}\right]\right.}{\left[\mathrm{H}^{+}\right]+\mathrm{K}_{1}} \\
\text { Rate }=\mathrm{k}_{\text {obs }}\left[\mathrm{Co}^{\mathrm{III}} \mathrm{W}_{12} \mathrm{O}_{40}^{5-}\right]_{\mathrm{T}}
\end{gathered}
$$

Comparing eqns. 5 and 6 :

$$
\begin{gathered}
\mathrm{k}_{\mathrm{obs}}=\frac{\mathrm{k}_{1} \mathrm{~K}_{1}[\mathrm{SH}]_{\mathrm{T}}}{\left[\mathrm{H}^{+}\right]+\mathrm{K}_{1}} \\
\frac{1}{\mathrm{k}_{\mathrm{obs}}=\frac{\left[\mathrm{H}^{+}\right]+\mathrm{K}_{1}}{\mathrm{k}_{1} \mathrm{~K}_{1}[\mathrm{SH}]_{\mathrm{T}}}}=\frac{1}{\mathrm{k}_{1}[\mathrm{SH}]_{\mathrm{T}}}+\frac{\left[\mathrm{H}^{+}\right]}{\mathrm{kK}_{1}[\mathrm{SH}]_{\mathrm{T}}} \\
\frac{[\mathrm{SH}]_{\mathrm{T}}}{\mathrm{k}_{\mathrm{obs}}}=\frac{1}{\mathrm{k}_{1}}+\frac{\left[\mathrm{H}^{+}\right]}{\mathrm{k}_{1} \mathrm{~K}_{1}}
\end{gathered}
$$

$[\mathrm{SH}]_{\mathrm{T}} / \mathrm{k}_{\mathrm{obs}}$ is plotted against $\left[\mathrm{H}^{+}\right]$(Fig. 4).

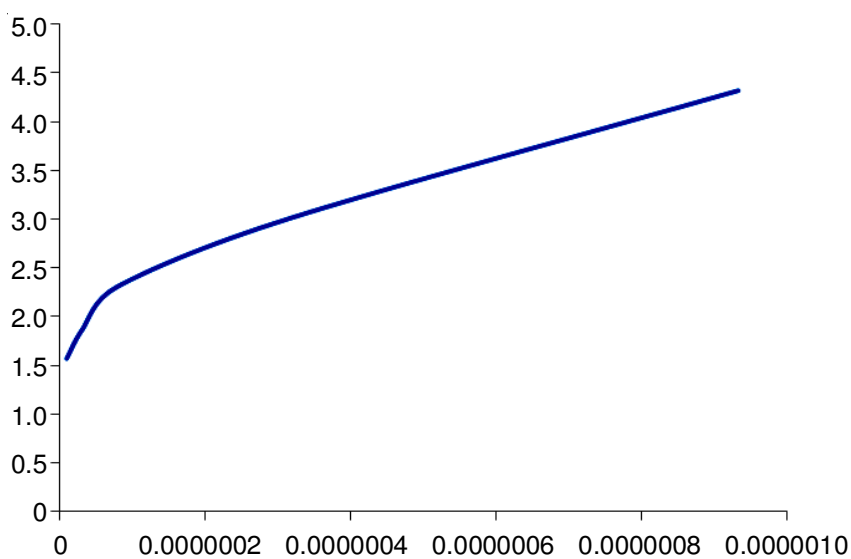

Fig. 4. Plot of variation of $[$ Diclofenac $] / \mathrm{k}_{\mathrm{obs}}$ versus $\left[\mathrm{H}^{+}\right]$at $298 \mathrm{~K}$ $[$ Diclofenac $]=2 \times 10^{-3},\left[\mathrm{Co}^{\mathrm{III}} \mathrm{W}_{12} \mathrm{O}_{40}{ }^{5-}\right]=5.0 \times 10^{-4}, \mathrm{I}=0.5 \mathrm{~mol} / \mathrm{L}$. $\left[\mathrm{H}^{+}\right]$was varied from $9.33 \times 10^{-7}$ to $1.0 \times 10^{-8} \mathrm{~mol} / \mathrm{L}$

$$
\begin{aligned}
& \text { Slope }=\frac{1}{\mathrm{k}_{1} \mathrm{~K}_{1}}, \text { Intercept }=\frac{1}{\mathrm{k}_{1}} \\
& \frac{\text { Intercept }}{\text { Slope }}=\mathrm{K}_{1}, \frac{1}{\text { Intercept }}=\mathrm{k}_{1}
\end{aligned}
$$

$\mathrm{K}_{1}, \mathrm{k}_{1}$, activation enthalpy and activation entropy are collected in Table-1.

TABLE-1

ELECTRON TRANSFER RATE CONSTANTS AT DIFFERENT TEMPERATURES AND ACTIVATION PARAMETERS AND THERMODYNAMIC PARAMETERS FOR THE REDOX REACTIONS OF 12-TUNGSTOCOBALTATE(III) WITH DICLOFENAC SODIUM

\begin{tabular}{lcccc}
\hline \multirow{2}{*}{ Parameters } & \multicolumn{4}{c}{ Temperature $(\mathrm{K})$} \\
\cline { 2 - 5 } & 293 & 298 & 303 & 308 \\
\hline $\mathrm{k}_{1}\left(\mathrm{~s}^{-1}\right)$ & 0.57 & 0.64 & 1.16 & 1.27 \\
$\mathrm{~K}_{1}(\mathrm{~mol} / \mathrm{L})$ & - & $5.33 \times 10^{-7}$ & - & - \\
$\Delta \mathrm{H}^{\#}\left(\mathrm{~kJ} \mathrm{~mol}^{-1}\right)$ & - & 42.87 & - & - \\
$\Delta \mathrm{S}^{\#}\left(\mathrm{~J} \mathrm{~K}^{-1} \mathrm{~mol}^{-1}\right)$ & - & -103.6 & - & - \\
\hline
\end{tabular}

Product analysis: The product [2-(2,6-dichlorophenylamino)phenyl]methanol is confirmed by its characteristic data of IR (Fig. 5). The broad peak at $3324 \mathrm{~cm}^{-1}$ is due to hydrogen bonded $-\mathrm{OH}$ group fused with secondary amine $-\mathrm{NH}$ stretching frequency and $\mathrm{C}-\mathrm{H}$ stretching frequency in the aromatic group. The peaks in $1694-1453 \mathrm{~cm}^{-1}$ region are due to $\mathrm{C}=\mathrm{C}$ aromatic group and $-\mathrm{NH}$ bending. $1283 \mathrm{~cm}^{-1}$ is due to $-\mathrm{OH}$ bending vibration. $\mathrm{CO}$ stretching at $1725-1700 \mathrm{~cm}^{-1}$ region is missing in the product. All the above data [17] corresponds to the formation of the product [2-(2,6-dichloro phenylamino)phenyl]methanol (Fig. 6)

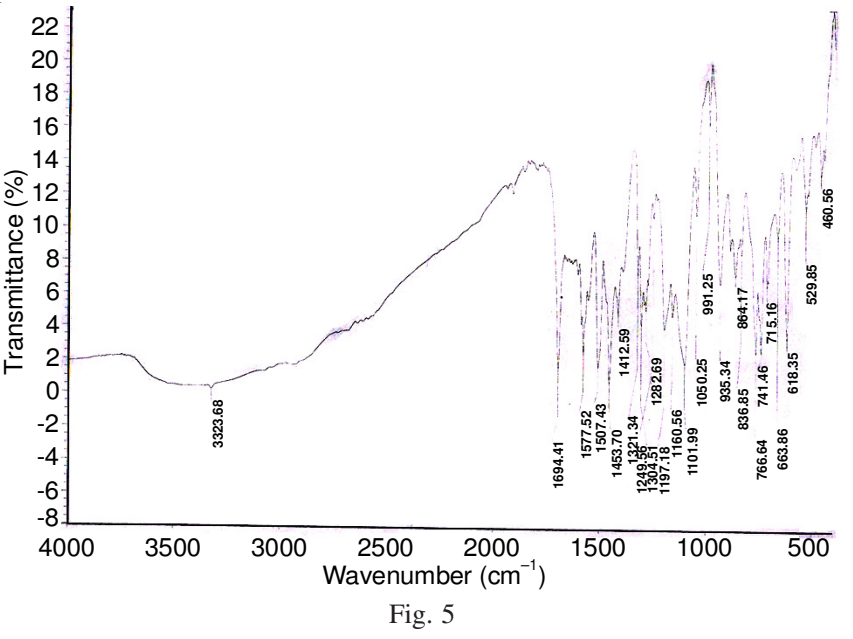

\section{Conclusion}

The oxidation of diclofenac sodium by 12-tungstocobalt(III) in aqueous medium was studied. The redox reaction showed first order dependence in [diclofenac sodium] and [12-tungstocobaltate(III)] and fractional order in $\left[\mathrm{OH}^{-}\right]_{\mathrm{T}}$. The activation parameters $\Delta \mathrm{H}^{\#}\left(\mathrm{~kJ} \mathrm{~mol}^{-1}\right)$ and $\Delta \mathrm{S}^{\#}\left(\mathrm{JK}^{-1} \mathrm{~mol}^{-1}\right)$ values are found to be 42.87 and -103.6 , respectively. The negative value of $\Delta \mathrm{S}^{\#}$ indicates an ordered transition state for the electron transfer reaction. The product is found to be [2-(2,6-dichloro phenylamino)phenyl]methanol. 


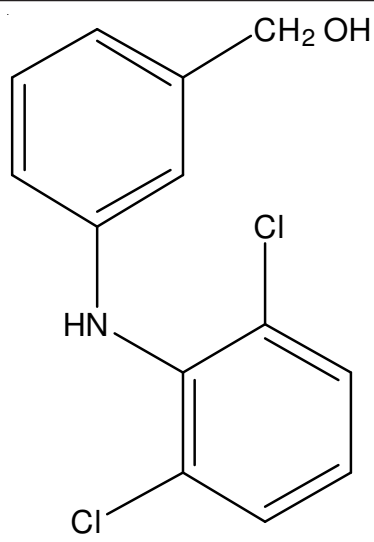

Fig. 6. Structure of [2-(2,6-dichloro phenylamino)phenyl]methanol

\section{REFERENCES}

1. J.P. Puttaswamy and J.P. Shubha, Am. Inst. Chem. Eng., 55, 3234 (2009); https://doi.org/10.1002/aic.11980.

2. E.C. Ku, J.M. Wsvary and W.D. Cash, Biochem. Pharmacol., 24, 641 (1975);

https://doi.org/10.1016/0006-2952(75)90186-0.

3. P.A. Todd and E.M. Sorkin, Drugs, 35, 244 (2012); https://doi.org/10.2165/00003495-198835030-00004.

4. N. Gostick, I.G.V. James, T.K. Khong, P. Roy, P.R. Shepherd and A.J. Miller, Curr. Med. Res. Opin., 12, 135 (1990); https://doi.org/10.1185/03007999009111494.
5. H. Yu, E. Nie, J. Xu, S. Yan, W.J. Cooper and W. Song, Water Res., 47, 1909 (2013); https://doi.org/10.1016/j.watres.2013.01.016.

6. L. Eberson, J. Am. Chem. Soc., 105, 3192 (1983); https://doi.org/10.1021/ja00348a039.

7. A.L. Nolan, R.C. Burns and G.A. Lawrance, J. Chem. Soc. Trans., 3041 (1998); https://doi.org/10.1039/a804598d.

8. M. Ali, S.K. Saha and P. Banerjee, J. Chem. Soc. Trans., 2305 (1991); https://doi.org/10.1039/dt9910002305.

9. Z. Amjad, J.C. Brodovitch and A. McAuley, Can. J. Chem., 55, 3581 (1977); https://doi.org/10.1139/v77-502.

10. A.G. Ayoko and A.M. Olatunji, Inorg. Chim. Acta, 80, 287 (1983); https://doi.org/10.1016/S0020-1693(00)91296-9.

11. S.K. Saha, M.C. Ghosh and P. Banerjee, Int. J. Chem. Kinet., 20, 699 (1988); https://doi.org/10.1002/kin.550200904.

12. P.K. Satpathy, G.C. Dash, S. Acharya and P. Mohanty, J. Indian Chem. Soc., 83, 891 (2006).

13. G.A.Ayoko and M.A. Olatunji, Polyhydron, 2, 577 (1983); https://doi.org/10.1016/S0277-5387(00)81513-2.

14. P. Kumari, A. Das, D.K. Baral, A.K. Pattanaik and P. Mohanty, E-J. Chem., 8, 1152 (2011); https://doi.org/10.1155/2011/341865.

15. P.K. Satpathy, G.C. Dash and P. Mohanty, Indian J. Chem., 47A, 1199 (2008).

16. P.G. Rasmussen and C.H. Brubaker Jr., Inorg. Chem., 3, 977 (1964); https://doi.org/10.1021/ic50017a011.

17. K. Nakamoto, Infrared and Raman Spectra of Inorganic compounds, John Wiley \& Sons, New York, edn 3 (1977). 